\title{
MODEL STRUKTURAL FAKTOR YANG BERPENGARUH TERHADAP PROFITABILITAS PERBANKAN GO PUBLIC DI INDONESIA
}

\author{
Oleh \\ Astohar \\ STIE Totalwin Semarang \\ astohardemak@gmail.com
}

\begin{abstract}
Abstrak
Efisiensi usaha dari suatu perusahaan termasuk pada perbankan dapat diketahui dari tingkat profitabilitasnya. Profitabilitas disini dapat dijadikan acuan untuk mengukur besarnya laba yang diperoleh. Profitabilitas bank dapat diukur dengan menggunakan rasio, salah satu rasionya adalah Return On Asset (ROA). ROA merupakan rasio yang digunkan untuk melihat tingkat efektivitas penggunaan aset untuk menghasilkan laba.. Penelitian ini menyempurnakan penelitian sebelumnya dengan rekomendasi untuk menambah variabel. Tambahan variabel untuk menyempurnakan penelitian tersebut adalah dengan menambah variabel non performing loan (NPL). Populasi dalam penelitian ini adalah sebanyak 43 perbankan yang tercatat sampai dengan tahun 2018. Pengumpulan data menggunakan panel data selama 5 tahun periode penelitian dengan metode pengambilan sampel menggunakan purposive sampling. Berdasarkan pertimbangan - pertimbangan diatas data yang digunakan sebagai sampel adalah 41 perbankan selama 5 tahun atau 205 observasi. Alat analisis menggunakan regresi berganda double step dan pengujian interveningnya menggunakan sobel test dengan program SPSS.

Hasil penelitian menunjukkan bahwa loan to deposit ratio (LDR) berpengaruh positif signifikan terhadap net interest margin ( $H_{1}$ tidak terbukti) sedangkan terhadap return on asset berpengaruh negatif tidak signifikan ( $\mathrm{H}_{5}$ tidak terbukti). BOPO berpengaruh negatif signifikan terhadap net interest margin $\left(\mathrm{H}_{2}\right.$ tidak terbukti) dan terhadap return on asset ( $H_{6}$ terbukti). Capital adequacy ratio (CAR) berpengaruh positif tidak signifikan terhadap net interest margin $\left(\mathrm{H}_{3}\right.$ tidak terbukti) sedangkan terhadap return on asset berpengaruh negatif tidak signifikan $\left(\mathrm{H}_{7}\right.$ tidak terbukti). Non performing loan (NPL) berpengaruh negatif signifikan terhadap net interest margin ( $H_{4}$ terbukti) juga terhadap return on asset ( $H_{8}$ tidak terbukti). Net interest margin terbukti berpengaruh positif dan signifikan terhadap return on asset ( $\mathrm{H}_{9}$ terbukti). Net interest margin mampu memediasi pengaruh BOPO dan NPL terhadap ROA, tapi tidak mampu memediasi LDR dan CAR.
\end{abstract}

\section{Kata kunci : LDR, BOPO, CAR, NPL, NIM dan ROA}

\section{PENDAHULUAN}

Perbankan dalam menjalankan usaha mengutamakan serta mengedepankan kepercayaan dan jasa. Menarik nasabah baru serta mempertahankan nasabah lamanya selalu menjadi upaya dari perbankan tersebut. Harapannya dari upaya tersebut adalah 
adanya peningkatan dana guna menunjang adanya peningkatan kredit yang diberikan serta jasa bank lainnya. Kesehatan dan tingkat profitabilitas yang tinggi dapat menunjang keberlangsungan serta kontinuitas bank tersebut. Profitabilitas yang tinggi menunjukkan bahwa perbankan tersebut mampu mencapai tingkat efisiensi yang tinggi bula. Sebaliknya jika bank tersebut dalam kondisi yang tidak sehat akan berakitbat pada lambannya kegiatan investasi serta pertumbuhan perekonomian (Astohar dan Praptitorini, 2019).

Efisiensi usaha dari suatu perusahaan termasuk pada perbankan dapat diketahui dari tingkat profitabilitasnya. Profitabilitas disii dapat dijadikan acuan untuk mengukur besarnya laba yang diperoleh. (Dhika, 2010 dalam Wibisono dan Wahyuni, 2017). Profitabilitas memiliki informasi untuk mengetahui besarnya tingkat laba yang diperoleh perusahaan dalam periode waktu tertentu dan produktivitas penggunaan dana perusahaan yang digunakan baik modal pinjaman maupun modal sendiri yang dapat digunakan oleh investor maupun calon investor sebagai dasar pengambilan keputusan dalam melakukan investasi. Profitabilitas tidak hanya penting bagi investor maupun calon investor saja tetapi juga penting (Pertiwi dan Susanto, 2019)

Menurut Bank Indonesia rasio profitabilitas yang penting bagi bank adalah return on asset (ROA) (Latifah dkk, 2012). Return on asset (ROA) digunakan untuk mengukur profitabilitas bank. Hal ini juga sejalan dengan arahan dari Bank Indonesia sebagai pembina dan pengawas perbankan yang saat ini dibawah naungan Otorita Jasa Keuangan (OJK) lebih mengutamakan nilai profitabilitas bank. Return on asset (ROA) yang semakin besar dapat dikatakan semakin tinggi pula tingkat keuntungan yang dicapai bank, yang tentunya semakin optimal posisi bank tersebut dari sisi penggunaan aktiva (asset) (Astohar, 2016).

Profitabilitas bank dapat diukur dengan menggunakan rasio, salah satu rasionya adalah Return On Asset (ROA). ROA merupakan rasio yang digunkan untuk melihat tingkat efektivitas penggunaan aset untuk menghasilkan laba (Riyadi 2008 dalam Yuniari dan Badjra, 2019). Profitabilitas untuk perbankan yang go public lebih tepat menggunakan return on asset (ROA), hal ini disebakan pada ROA lebih memfokuskan kemampuan perbankan untuk memperoleh earning dalam operasi perusahaan, sedangkan Return On Equity (ROE) hanya mengukur return yang 
diperoleh dari investasi pemilik perusahaan dalam bisnis tersebut (Marwadi, 2005, dalam Astohar, 2018)

Banyak fakor yang mempengaruhi profitabilitas perbankan seperti loan to deposit ratio (LDR), biaya operasional dan pendapatan operasional (BOPO) dan capital adequacy Ratio secara langsung atau melalui net interest margin (NIM) yang sebagai variable intervening (Astohar dan Praptitorini, 2019). Saran dari penelitian Astohar dan Praptitorini (2019) adalah menambah variabel yang mempengaruhi profitabilitas perbankan. Dalam penelitian ini dengan menambah variabel non performin loan (NPL) untuk memenuhi saran atau agenda mendatang dari penelitian sebelumnya.

Variabel non performing loan (NPL) dipilih untuk menambah model penelitian saat ini adalah masih adanya perbedaan hasil penelitian (research gap). Hasil penelitian dari Feri dan Sedana (2018) menunjukkan bahwa non performing loan (NPL) berpengaruh profitabilitas. Hasil penelitian ini didukung oleh Putriningsih dan Yulianto (2016) serta Pertiwi dan Susanto (2019). Hasil penelitian ini berbeda dengan penelitian dari Million (2017 serta Ali dan Laksono (2017) yang mana non performing loan (NPL) tidak berpengaruh profitabilitas yang diproksi dengan return on assets (ROA).

Permasalahan dalam penelitian ini adalah menyempurnakan penelitian dari Astohar dan Praptitorini (2019) dengan menambah variable non performing loan (NPL) juga mempunyai dampak yang negative dan signifikan terhadap profitabilitas bank atau yang tidak berpengaruh signifikan. Selain permasalahan dari research gap penelitian ini juga ada permasalahan adanya profitiablitas perbankan yang go public yang berflukuatif (naik dan turun) selama 5 tahun terakhir.

Pada penelitian sebelumnya teori yang digunakan adalah teori anticipated income theory menunjukkan bahwa bankir mulai melihat portofolio pinjaman mereka sebagai sumber likuiditas. Teori ini mendorong para bankir untuk memperlakukan pinjaman jangka panjang sebagai sumber potensial likuiditas. Teori kedua adalah Teori Trade Off Between Liquidity and Profitability yaitu perbankan satu sisi harus menjaga posisi likuiditasnya melalui peningkatan cadangan kas, akibat yang ditimbulkan sebagian dana menganggur (idle fund). Akibatnya, tingkat profitabilitas menurun. Pada penelitian ini dengan pendekatan perilaku manajemen dengan 
pendekatan tiga hipotesis yaitu bad luck hypothesis, bad management hypothesis dan skimping hypothesis.

\section{LANDASAN TEORITIS DAN PENGEMBANGAN HIPOTESIS}

\section{Profitabilitas}

Profitabilitas merupakan kemampuan perusahaan dalam memperoleh laba atau ukuran efektivitas pengelolaan manajemen perusahaan (Wiagustini, 2014). Setiap perusahaan yang dimaksud disini adalah bank, akan menjaga tingkat profitabilitas karena merupakan cerminan dari kinerja perusahaan. Semakin tinggi profitabilitas, semakin efisien pula pengelolaan modal dalam perusahaan (Yuniari dan Badjra, 2019). Tingkat profitabilitas menunjukkan kinerja sebuah perusahaan dalam memperoleh profit. Rasio profitabilitas menurut (Kasmir, 2014) adalah rasio yang digunakan untuk menilai kinerja dan kemampuan sebuah perusahaan dalam memperoleh profit atau laba.

Return on Asset (ROA) adalah rasio perbandingan antara laba setelah pajak dengan total aktiva (total asset) yang digunakan untuk mengukur kemampuan perusahaan dalam menghasilkan laba atas aktiva (total asset) yang dipergunakan dalam periode tertentu (Fauziah, 2011). Apabila ROA perusahaan terjadi peningkatan dari tahun ke tahun, maka bisa dikatakan perusahaan semakin efisien dalam mengelola bisnisnya. Semakin besar ROA maka kondisi bank akan semakin baik. (ROA) atau hasil pengembalian atas aset merupakan rasio yang menunjukkan hasil atas penggunaan aset perusahaan dalam menciptakana laba bersih, dengan kata lain rasio ini digunakan untuk mengukur seberapa besar jumlah laba bersih yang akan dihasilkan dari setiap rupiah dana yang tertanam dalam total aset (Hery 2015).

Return On Asset (ROA) adalah rasio profitabilitas yang digunakan untuk melihat perbandingan laba sebelum pajak dengan total aset bank, ratio ini menunjukkan tingkat efisiensi pengelolaan aset bank untuk menghasilkan keuntungan atau laba (Riyadi, 2008). Perusahaan dapat dikatakan mendapat keuntungan dari penggunaan total asetnya jika ROA yang dihasilkan positif. Jika ROA yang dihasilkan negatif, maka total aset yang digunakan untuk beroperasi tidak mampu mengasilkan keuntungan (rugi) (Yuniari dan Badjra, 2019).

\section{Net interest margin (NIM)}


Net Interest Margin (NIM) rasio ini merupakan rasio untuk mengukur kemampuan manajemen bank dalam mengelola aset produktifnya dalam menghasilkan pendapatan bunga bersih. memberikan penjelasan bahwa Net Interest Margin (NIM), adalah rasio yang pengukurannya menggunakan perbandingan antara pendapatan bunga bersih dengan rata-rata aktiva produktif. Pendapatan bunga bersih didapatkan dari hasil pengurangan pendapatan bunga dengan beban bunga. Rasio NIM digunakan untuk mengukur kemampuan dari manajemen perbankan dalam mengelola seluruh aktiva produktifnya dalam rangka menghasilkan pendapatan bunga bersih (Pandia, 2012 dalam Pertiwi dan Susanto, 2019).

Net Interest Margin (NIM) adalah perbandingan antara Interest Income (pendapatan bunga) dikurangi Interest Expenses (biaya bunga bank yang menjadi beban) dibagi dengan Average Interest Earning Assets (rata-rata aktiva produktif yang digunakan). Net interest margin (NIM) digunakan untuk mengukur kemampuan bank dalam menghasilkan pendapatan dari bunga dengan melihat kinerja bank dalam menyalurkan kredit, dimana semakin besar NIM yang dicapai suatu bank maka akan meningkatkan pendapatan bunga atas aktiva produktif yang dikelola oleh bank yang bersangkutan, sehingga laba bank (ROA) akan meningkat (Astohar dan Praptitorini, 2019).

Net interest margin (NIM) mempunyai pengaruh yang positif dan signifikan terhadap Profitabilitas perbankan (Ariyanti, dkk, 2017). Hal ini juga diperkuat oleh Astohar dan Praptitorini (2019) bahwa semakin besar perubahan net interest margin (NIM) suatu bank, maka semakin besar pula profitabilitas bank tersebut, yang berarti kinerja keuangan tersebut semakin meningkat. Semakin besar rasio ini maka akan meningkatkan pendapatan bunga atas aktiva produktif yang dikelola bank, sehingga kemungkinan suatu bank dalam kondisi bermasalah semakin kecil dan kinerja perbankan tersebut akan semakin baik (Pinasi dan Mustikawati, 2018). Pertiwi dan Susanto (2019) memperkuat argument peneliti sebelumnya yaitu semakin tinggi net interest margin (NIM) akan berdampak pada peningkatan profitabilitas perbankan yang diproksi dengan return on asset. Berdasarkan argumen tersebut dapat dirumuskan hipotesis kesembilan $\left(\mathrm{H}_{9}\right)$ sebagai berikut :

$\mathrm{H}_{9}$ : net interest margin (NIM) mempunyai pengaruh yang positif dan signifikan terhadap return on asset (ROA) Bank Go Public

\section{Loan To Deposit Ratio (LDR)}


Loan to Deposit Ratio $(L D R)$ merupakan h perbandingan jumlah kredit terhadap Dana Pihak Ketiga (DPK), dimana rasio ini menunjukkan kemampuan suatu bank dalam menyalurkan dana yang berasal dari masyarakat seperti tabungan, giro, deposito berjangka, sertifikat deposito berjangka dan kewajiban lainnya dalam bentuk kredit (Taswan, 2010). Lebih lanjut Kasmir, (2014 dalam Pertiwi dan Susanto, 2019) menyatakan bahwa rasio Loan to Deposit Ratio $(L D R)$ merupakan rasio yang digunakan dalam perhitungan total kredit yang diberikan dan membandingkannya dengan total penggunaan modal sendiri dengan total dana masyarakat.

Menurut Sudarmawati dan Pramono (2017) peningkatan loan to deposit ratio (LDR) menunjukkan kurangnya efektifitas bank dalam menyalurkan kredit sehingga hilangnya kesempatan bank untuk memperoleh laba. Loan to deposit ratio mempunyai pengaruh yang negatif dan signifikan terhadap profitabilitas (Astohar, 2016). Loan to deposit ratio yang tinggi menunjukkan kredit yang diberikan kepada masyarkaat atau nasabah adalah lebih besar dari dana pihak ketiga yang diterima, hal ini berdampak pada kemungkinan peningkatan risiko (Feri dan Sedana, 2018) dan dampaknya adalah justru akan menurunkan profitabilitas bank (Ali dan Laksono, 2017) serta (Yuniari dan Badjra, 2019). Berdasarkan argument tersebut dapat dirumuskan hipotesis kedua $\left(\mathrm{H}_{1}\right)$ dan Keepat $\left(\mathrm{H}_{4}\right)$ sebagai berikut : Berdasarkan argumen tersebut dapat dirumuskan hipotesis kedua $\left(\mathrm{H}_{1}\right)$ dan Kelima $\left(\mathrm{H}_{5}\right)$ sebagai berikut :

$\mathrm{H}_{1}$ : loan to deposit ratio $(L D R)$ mempunyai pengaruh yang negative dan signifikan terhadap net interest margin (NIM)

$\mathrm{H}_{5}$ : loan to deposit ratio $(L D R)$ mempunyai pengaruh yang negative dan signifikan terhadap return on asset ( $R O A)$

\section{Pengaruh Biaya Operasional dan Pendapatan Operasional (BOPO)}

Menurut Sulistyono (2014) efisiensi merupakan suatu rasio utnuk mengukur dan membandingkan nilai dari output dari suatu proses dengan nilai inputnya. Output dalam hal ini adalah pendapatan total dari hasil operasi dalam suatu periode, sedangkan input merupakan total biaya yang dikeluarkan untuk memperoleh pendapatan tersebut. Salah satu rasio yang digunakan mengukur efisiensi adalah biaya operasional dan Pendapatan operasional atau BOPO (Yuniari dan Badjra (2019). BOPO merupakan rasio yang digunakan untuk mengukur efisiensi usaha yang 
dilakukan bank atau untuk mengukur besarnya biaya bank yang dikelurkan untuk memperoleh pendapatan dari aset. Efisiensi mencerminkan kinerja bank yang dilihat dari input dan output yang dihasilkan oleh bank. Salah satu cara untuk melihat efesiensi bank adalah dengan membandingkan biaya operasional dengan pendapatan operasional bank (Yuniari dan Badjra, 2019).

Hasil penelitian dari Wibisono (2017) menunjukkan bahwa BOPO mempunyai pengaruh yang negative terhadap profitabilitas. Meningkatnya rasio BOPO akan berdampak pada penurunan profitabilitas (ROA) (Ariyanti, 2017). Hal ini menunjukkan bahwa tingginya biaya operasional akan berdampak pada turunnya pendapatan, sehingga menurunkan stabilitas perbankan (Pinasi dan Martindas, 2018). Hal yang sama ditemukan oleh Yuniari dan Badjra, 2019 bahwa variabel efisiensi operasi yang diproksikan dengan BOPO berpengaruh negatif terhadap kinerja perbankan yang diproksikan dengan Return on Assets (ROA). Berdasarkan argumen tersebut dapat dirumuskan hipotesis kedua $\left(\mathrm{H}_{2}\right)$ dan Hipotesis keenam $\left(\mathrm{H}_{6}\right)$ sebagai berikut :

$\mathrm{H}_{2}$ : BOPO mempunyai pengaruh yang negative dan signifikan terhadap net interest $\operatorname{margin}(N I M)$

$\mathrm{H}_{6}$ : BOPO mempunyai pengaruh yang negative dan signifikan terhadap return on asset (ROA)

\section{Capital Adequacy Ratio (CAR)}

Capital Adequacy Ratio atau sering disebut dengan istilah rasio kecukupan modal bank, yaitu bagaimana sebuah perbankan mampu membiayai aktivas kegiatannya dengan kepemilikan modal yang dimilikinya (Fahmi, 2015). Lebih lanjut capital adequacy ratio juga merupakan rasio kinerja bank untuk mengukur kecukupan modal yang dimiliki bank untuk menunjang aktiva yang mengandung atau menghasilkan resiko (Astohar dan Praptitorini, 2019). Rasio ini yang berfungsi menampung risiko kerugian yang kemungkinan dihadapi oleh bank. Semakin tinggi CAR, maka semakin baik kemampuan bank tersebut untuk menanggung risiko dari setiap kredit / aktiva produktif yang berisiko tertimbang untuk menunjang aktiva yang mengandung atau mengahasilkan resiko, misalnya kredit yang diberikan (Rahmani, 2017)

Semakin tinggi rasio $C A R$ maka profitabilitas bank mengalami peningkatan karena jika rasio $C A R$ tinggi, maka perusahaan dinilai dapat mendanai segala aktivitas 
operasional sehingga pada akhirnya dapat memberikan kontribusi terhadap profitabilitas perbankan. (Setiawan, 2017; Soares dan Yunanto, 2018) menyatakan bahwa variabel Capital Adequacy Ratio (CAR) tidak berpengaruh signifikan terhadap Return On Assets. Namun, (Musnadi, 2014; Haryanto, 2016) menyatakan terdapat pengaruh signifikan positif dari variabel CAR terhadap Return On Assets. Hasil lainnya ditemukan oleh (Irman dan Wulansari, 2016), dimana CAR memiliki pengaruh signifikan negatif terhadap Return On Assets

Besaran CAR akan membuat bank mampu menghadapi peyusutan nilai harta bank yang timbul akibat dari adanya resiko yang terjadi. Tingginya CAR mengindikasikan bahwa bank tersebut mampu membiayai kegiatan operasional dan memberikan kontribusi yang cukup besar bagi profitabilitas (Aprillya dkk, 2017). Menurut Pardede dan Pangestuti (2016) yang mana hasil penelitian menunjukan bahwa capital adequacy ratio (CAR) yaitu kenaikan dari CAR tidak serta merta meningkatkan profitabilitas bank. Lebih lanjut hasil penelitian dari Astohar dan Praptitorini (2019) menunjukkan bahwa peningkatan capital adequacy ratio (CAR) justru menurunkan profitabilitas perbankan. Hal ini disebabkan peningkatan CAR justru membuat dana yang menganggur juga akan meningkat atau terjadi inefisien (Supriyadi dan Purnomo (2019). Berdasarkan argumen peneliti diatas dapat ditarik hipotesis ketiga $\left(\mathrm{H}_{3}\right)$ dan hipotesis ketujuh $\left(\mathrm{H}_{7}\right)$ sebagai berikut :

$\mathrm{H}_{3}$ : capital adequacy ratio modal berpengaruh negative dan signifikan terhadap net interest margin (NIM)

$\mathrm{H}_{7}$ : capital adequacy ratio modal berpengaruh negative dan signifikan terhadap return on asset (ROA)

\section{Non Performing Loan (NPL)}

Non Performing Loan (NPL) adalah kredit bermasalah terhadap total kredit dari kredit yang diberikan kepada pihak ketiga tidak termasuk kredit kepada bank lain. Sedangkan kredit bermasalah adalah kredit dengan kualitas kurang lancar, diragukan dan macet. Non performing loan (NPL) merupakan rasio yang menunjukkan kemampuan bank dalam mengelola kredit bermasalah yang diberikan oleh Bank. Peraturan Bank Indonesia No 6/10/PBI/2004 Tanggal 12 April 2004 tentang Sistem Penilaian Kesehatan Bank Umum menentukan nilai rasio NPL bank tidak boleh melebihi 5\%, 
jika suatu bank memiliki nilai NPL lebih dari 5\% maka bank tersebut dianggap tidak sehat (Sitepu, 2016).

Semakin tinggi rasio NPL maka semakin buruk kualitas kredit yang menyebabkan jumlah kredit bermasalah semakin besar sehingga dapat menyebabkan kemungkinan suatu bank dalam kondisi bermasalah semakin besar. Setelah kredit diberikan, bank wajib melakukan pemantauan terhadap penggunaan kredit serta kemampuan dan kepatuhan debitur dalam memenuhi kewajiban (Astohar, 2018). Bank yang mempunyai NPL yang tinggi, maka akan memperbesar biaya, baik biaya pencadangan aktiva produktif maupun biaya lainnya, dengan kata lain semakin tinggi NPL suatu bank, maka hal tersebut akan mengganggu kinerja bank tersebut (Ali, 2004 dalam Pinasi dan Mustikawati, 2018). Tingginya tingkat kredit bermasalah menyebabkan tertundanya pendapatan bank yang seharusnya dapat diterima, sehingga menurunkan tingkat profitabilitas suatu bank (Pinasi dan Mustikawati, 2018).

Hasil penelitian dari Muslim dan Chabachib (2016) bahwa non performing loan $(N P L)$ mempunyai pengaruh yang negatif terhadap profitabilitas. Meningkatnya non performing loan (NPL) akan berdampak terhadap menurunnya efisiensi bank dan profitabilitas perbankan (Astohar, 2018). Non perfoming loan (NPL) yang tinggi akan memperbesar biaya, sehingga berpotensi terhadap kerugian bank. Semakin tinggi rasio ini amka akan semakin buruk kualitas kredit bank yang menyebabkan jumlah kredit bermasalah semakin besar (Feri dan Sedana, 2018). Kredit bermasalah yang semakin besar berdampak pada efisiensi dan efektivitas yang menurun (Pertiwi dan Susanto, 2019).

Berdasarkan argument peneliti diatas dapat ditarik hipotesis ketiga $\left(\mathrm{H}_{4}\right)$ dan hipotesis kedelapan $\left(\mathrm{H}_{8}\right)$ sebagai berikut :

$\mathrm{H}_{4}$ : non performing loan (NPL) berpengaruh negative dan signifikan terhadap net interest margin (NIM)

$\mathrm{H}_{8}$ : non performing loan (NPL) modal berpengaruh negative dan signifikan terhadap return on asset ( $R O A)$

\section{Kerangka Pemikiran}

Kerangka pikir dalam penelitian ini adalah sebagai berikut :

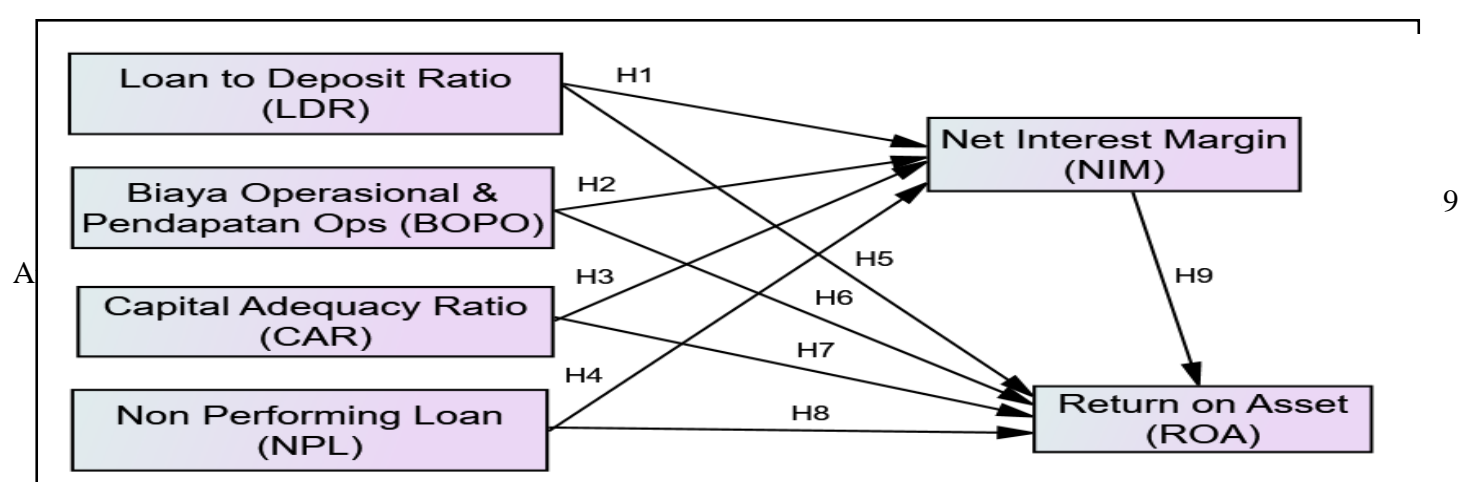




\section{Gambar 1. Kerangka Pemikiran}

\section{METODE PENELITIAN}

\section{Jenis dan Metode Pengumpulan Data}

Data yang digunakan adalah berupa laporan keuangan publikasi tahunan yang diterbitkan oleh Bank Indonesia yang diperoleh dari WEB OJK dari periode tahun 2014 sampai tahun 2018. Sumber data yang digunakan ini diperoleh melalui penelusuran dari media internet dari www. ojk.go.id.Metode pengumpulan data yang digunakan yaitu melalui studi pustaka dari direktori perusahaan go publik dan situs resmi tiap perusahaan.idx.go.id. serta situs - situr resmi lainnya yang dijadikan sampel.

\section{Alat Analisis Data}

\section{Uji Persamaan Regresi Ganda Tahap 1}

Analisis regresi linier berganda adalah pengaruh secara linier antara dua atau lebih variabel bebas (independen) dengan satu variabel dependen, yaitu pengaruh dari loan to deposit ratio $(L D R)$, biaya operasional terhadap pendapatan operasional (BOPO), capital adequacy ratio (CAR) dan non performing loan (NPL) terhadap net interest margin (NIM) (Astohar, 2013). Persamaan regresi pada penelitian ini terdapat dua model. yaitu sebagai berikut: $Y_{1}=a+b_{1} X_{1}+b_{2} X_{2}+b_{3} X_{3}+b_{4} X_{4}+b_{5} X_{5}$

Dimana : $Y_{1}: N I M ; X_{1}: L D R ; X_{2}: B O P O ; X_{3}: C A R ; X_{4}: N P L$

\section{Uji Persamaan Regresi Ganda tahap 1}

Analisis regresi linier berganda adalah pengaruh secara linier antara dua atau lebih variabel independen dengan satu variabel dependen, yaitu pengaruh dari capital adequacy ratio $(C A R)$, loan to deposit ratio $(L D R)$, dan biaya operasional terhadap pendapatan operasional (BOPO), non performing loan (NPL) serta net interest margin (NIM) terhadap return on asset (ROA). Sebelum melakukan estimasi yang tidak biasa dengan analisis regresi, perlu dilakukan uji t dan uji Fit data yaitu pengujian antar variabel bebas supaya tidak terjadi multikolinieritas, heteroskedastisitas, normalitas, 
dan autokorelasi (Astohar, 2013). Persamaan regresi pada penelitian ini terdapat dua model. yaitu sebagai berikut: $Y_{2}=a+b_{1} X_{1}+b_{2} X_{2}+b_{3} X_{3}+b_{4} X_{4}+b_{5} X_{5}$

Dimana : $\mathrm{Y}_{2}$ : ROA; $\mathrm{X}_{1}$ : CAR; $\mathrm{X}_{2}:$ LDR; $\mathrm{X}_{3}: \mathrm{BOPO} ; \mathrm{X}_{4}: \mathrm{NPL} ; \mathrm{Y}_{1}: \mathrm{NIM}$

\section{Uji Persamaan Regresi Sederhana}

Analisis regresi linier sederhana adalah pengaruh secara linier antara variabel independen dengan variabel dependen, yaitu pengaruh dari net interest margin (NIM) terhadap Return on Asset (ROA). Sebelum melakukan estimasi yang tidak biasa dengan analisis regresi, perlu dilakukan uji t dan uji Fit data yaitu pengujian antar variabel bebas supaya tidak terjadi multikolinieritas, heteroskedastisitas, normalitas, dan autokorelasi (Astohar, 2013). Persamaan regresi pada penelitian ini terdapat dua model. yaitu sebagai berikut: $\mathrm{Y}_{2}=\mathrm{a}+\mathrm{b}_{5} \mathrm{Y}_{1}$

\section{Uji Koefisien Determinasi}

Koefisien determinan pada penelitian ini digunakan untuk melihat berapa persen dari variasi variabel terikat dijelaskan variabel bebas. Pada penelitian ini koefisien determinasi adalah mengetahui seberapa besar variasi profitabilitas Bank Go Public (ROA) dapat diterangkan oleh variasi dari capital adequacy ratio (CAR), loan to deposit ratio $(L D R)$, biaya operasional terhadap pendapatan operasional (BOPO), non performing loan (NPL) serta net interest margin (NIM). Nilai determinasi yang digunakan pada penelitian ini adalah nilai adjusted $R^{2}$. Digunakannya nilai tersebut karena nilai adjusted $R^{2}$ pada saat mengevaluasi model regresi dapat naik atau turun apabila satu variabel independen ditambahkan ke dalam model (Ghozali, 2013).

\section{Sobel Test}

Uji Sobel ini dilakukan dengan cara menguji kekuatan pengaruh tidak langsung variabel independen (X) kepada variabel dependen (Y) melalui variabel intervening (M) dalam hal ini adalah menguji pengaruh tidak langsung variabel capital adequacy ratio, loan to deposit dan biaya operasional terhadap pendapatan opersional secara tidak langsung terhadap return on asset melalui net interest margin. Suatu variabel disebut variabel intervening jika variabel tersebut ikut mempengaruhi hubungan antara variabel prediktor (independen) dan variabel criterion (dependen) (Baron dan Kenny (1986) dalam Ghozali (2009). Pengujian hipotesis mediasi dapat dilakukan dengan prosedur yang dikembangkan oleh Sobel (1982) dan dikenal dengan Uji Sobel (Sobel Test). 


\section{HASIL DAN PEMBAHASAN}

Pada variable profitabilitas Bank Go Public (ROA) yang rata-ratanya adalah sebesar 1,19\%. Berdasarkan rata - rata, Bank Go Public masuk dalam kategori yang kurang sehat, hal ini ditandai dengan rata - rata return on asset Bank Go Public masih dibawah 1,5\% (Ketentuan Bank Indonesia > 1,5 \%). Berdasarkan data yang diperoleh profitabilitas Bank Go Public (ROA) terendah pada periode penelitian yaitu sebesar 9,58 \% yaitu pada PT. Bank Pundi Indonesia Tbk pada tahun 2016. Rasio profitabilitas Bank Go Public (ROA) tertinggi adalah pada Bank Permata, Tbk pada tahun 2015 yaitu sebesar $6,72 \%$.

Pada variabel loan to deposit ratio $(L D R)$ ini menunjukkan bahwa berdasarkan rata - rata Bank Go Public masuk dalam kategori yang sehat, hal ini ditandai dengan rata - rata loan to deposit ratio (LDR) masih dikisaran 84,83\% (Ketentuan Bank Indonesia $85 \%$ sampai dengan $110 \%$ ). Loan to deposit ratio (LDR) yang paling rendah pada penelitian yaitu sebesar $41,99 \%$ adalah pada Bank Mitra Niaga, Tbk pada tahun 2018. Rasio loan to deposit ratio (LDR) yang tertinggi adalah pada Bank Woori Saudara Indonesia pada tahun 2018 yaitu sebesar 145,26\%.

Pada variabel rasio beban operasional dibanding dengan pendapatan operasional (BOPO) ini menunjukkan bahwa berdasarkan rata - rata Bank Go Public masuk dalam kategori yang sehat, hal ini ditandai dengan rata - rata BOPO masih dikisaran 89,14 \% (Ketentuan Bank Indonesia < $100 \%$ ). Berdasarkan deskriptif data yang didapatkan BOPO terendah pada selama periode penelitian adalah sebesar 9,17\% pada Bank Permata, Tbk pada tahun 2015. Rasio BOPO tertinggi adalah pada Bank MNC International, Tbk pada tahun 2017 yaitu sebesar 180,62\%.

Pada variabel capital adequacy ratio $(C A R)$ ini menunjukkan bahwa berdasarkan rata - rata Bank Go Public masuk dalam kategori yang sehat, hal ini ditandai dengan rata - rata capital adequacy ratio (CAR) masih dikisaran 20,50\% (Ketentuan Bank Indonesia > $8 \%$ ). Capital adequacy ratio $(C A R)$ terendah pada periode penelitian yaitu sebesar 10,04 \% yaitu pada Bank Pundi Indonesia, Tbk pada tahun 2018. Rasio capital adequacy ratio (CAR) tertinggi adalah pada Bank Ina Perdana, Tbk pada tahun 2017 yaitu sebesar 66,43\%.

Pada variabel non performing loan (NPL) ini menunjukkan bahwa berdasarkan rata - rata Bank Go Public masuk dalam kategori yang sehat, hal ini 
ditandai dengan rata - rata non performing loan (NPL) masih dikisaran 2,96\% (Ketentuan Bank Indonesia < 5 \%). non performing loan $(N P L)$ terendah pada periode penelitian yaitu sebesar 0,002 \% yaitu pada Bank National Nobu, Tbk pada tahun 2015. Rasio non performing loan (NPL) tertinggi adalah pada Bank Yudha Bakti, Tbk pada tahun 2018 yaitu sebesar $15,75 \%$.

Pada variabel rasio net interest margin (NIM) ini menunjukkan bahwa berdasarkan rata - rata Bank Go Public masuk dalam kategori yang sehat, hal ini ditandai dengan rata - rata NIM masih dikisaran 5,09 \% (Ketentuan Bank Indonesia > 1,5\%). Berdasarkan deskriptif data yang didapatkan net interest margin (NIM) terendah pada selama periode penelitian adalah sebesar 0,24\% pada Bank Jtrust Indonesia pada tahun 2014. Rasio net interest margin (NIM) tertinggi adalah pada Bank Tabungan Pensiunan Nasional, Tbk sebesar 11,98\%.

\section{Uji Asumsi Klasik}

Data yang digunakan untuk penelitian terdistribusi secara normal, yang ditandai dengan print out grafik erlihat titik-titiknya nampak menyebar menjauh atau tidak berada disekitar pada garis diagonal, serta penyebaran titik - titiknya tidak mengikuti garis diagonal. Selain pada grafik histogram yang menunjukkan data tersebar tidak mendekati garis normalitas. Berdasarkan uji Kolmogorov Smirnov sebesar 0,415 yang mana nilai signifikansi tersebut lebih besar dari nilai signifikansi yang telah ditentukan yaitu 0,05. Berdasarkan data tersebut dapat dijelaskan bahwa model regresi telah terdistribusi secara normal.

Hasil pengujian penyimpangan asumsi klasik menunjukkan bahwa model tidak terjadi penyimpangan multikolinearitas yang ditandai dengan nilai VIF dibawah 10 yaitu : 1,$124 ; 1,425 ; 1,088 ; 1,285$ dan 1,235 serta nilai tolerance diatas 0,1 yaitu 0,$890 ; 0,702 ; 0,919 ; 0,778$ dan 0,810 . Grafik scatterplot tidak membentuk pola yang khusus atau jelas, hal ini menunjukkan data tidak terjadi penyimpangan heteroskedastisitas. Nilai durbin Watson sebesar 1,756 yang mana nilai tersebut berada pada daerah tidak tidak terjadi autokorelasi.

Hasil perhitungan anova didapatkan nilai $\mathrm{F}$ hitungnya sebesar 1620,945 nilai probabilitas adalah 0,000 . Hasil ini dikatakan bahwa permodelan yaitu variabel bebas yang berupa LDR, BOPO dan CAR secara bersama - sama (simultan) mempunyai 
pengaruh signifikan terhadap profitabilitas pada Bank Go Public, atau model yang dibangun memenuhi kriteria fit.

\section{Analisis Regresi Linier Berganda Tahap 1}

Persamaan sebagai berikut

$\mathrm{NIM}=5,575+0,022 \mathrm{LDR}-0,031 \mathrm{BOPO}+0,033 \mathrm{CAR}-0,080 \mathrm{NPL}$

Nilai konstanta pada penelitian ini diperoleh nilai 5,734 yang dapat diartikan bahwa tanpa adanya perubahan dari variabel bebas atau variabel LDR, BOPO dan CAR maka pendapatan bunga (net interest margin) pada Bank Go Public mengalami peningkatan

Loan to deposit ratio (LDR) Bank Go Public di Indonesia mempunyai pengaruh positif terhadap pendapatan bunga (net interest margin) dengan koefisien regresi sebesar 0,022. Hal ini dapat diartikan bahwa setiap peningkatan Loan to deposit ratio $(L D R)$ maka pendapatan bunga (net interest margin) pada Bank Go Public di Indonesia mengalami peningkatan pula. Hipotesis diterima, karena ditunjukkan dengan nilai probabilitas (sig) sebesar 0,020 yang mana nilai tersebut dibawah 0,05.

Biaya operasional dan pendapatan opoerasional (BOPO) Bank Go Public di Indonesia mempunyai pengaruh negatif terhadap profitabilitas bank dengan koefisien regresi sebesar - 0,031. Hal ini dapat diartikan bahwa setiap peningkatan BOPO maka profitabilitas pada Bank Go Public di Indonesia mengalami penurunan atau sebaliknya setiap penurunan BOPO akan meningkatkan profitabilitas. Hipotesis diterima, karena dibuktikan dengan nilai probabilitas (sig) sebesar 0,000 yang mana nilai tersebut dibawah 0,05 .

Capital adequacy ratio (CAR) Bank Go Public di Indonesia mempunyai dampak positif terhadap pendapatan bunga (net interest margin) bank dengan koefisien regresinya sebesar 0,033. Ini dapat dijelaskan setiap adanya peningkatan Capital adequacy ratio $(C A R)$ atau semakin tinggi CAR maka pendapatan bunga (net interest margin) Perkreditan Rakyat di Indonesia akan mengalami peningkatan. Hipotesis ditolak pada taraf signifikan $5 \%$, ini ditunjukkan melalui nilai probabilitas (sig) sebesar 0,092 di mana nilai probabilitas tersebut diatas 0,05.

Non performing loan (NPL) Bank Go Public di Indonesia mempunyai pengaruh negatif terhadap profitabilitas bank dengan koefisien regresi sebesar - 0,081. Hal ini dapat diartikan bahwa setiap peningkatan non performing loan (NPL) maka 
profitabilitas pada Bank Go Public di Indonesia mengalami penurunan atau sebaliknya setiap penurunan non performing loan (NPL) akan meningkatkan profitabilitas. Hipotesis diterima, karena dibuktikan dengan nilai probabilitas (sig) sebesar 0,000 yang mana nilai tersebut dibawah 0,05 .

\section{Analisis Regresi Linier Berganda Tahap 2}

Persamaan kedua sebagai berikut $\mathrm{ROA}=9,733+0,001 \mathrm{LDR}-0,094 \mathrm{BOPO}-0,002 \mathrm{CAR}-0,083 \mathrm{NPL}$

Nilai konstanta pada penelitian ini diperoleh nilai 9,733 yang dapat diartikan bahwa tanpa adanya perubahan dari variabel bebas atau variabel LDR, BOPO, CAR dan NPL maka profitabilitas pada Bank Go Public mengalami peningkatan

Loan to deposit ratio (LDR) Bank Go Public di Indonesia mempunyai pengaruh positif terhadap profitabilitas bank dengan koefisien regresi sebesar 0,001. Hal ini dapat diartikan bahwa setiap peningkatan Loan to deposit ratio (LDR) maka profitabilitas pada Bank Go Public di Indonesia mengalami penurunan. Hipotesis ditolak, karena ditunjukkan dengan nilai probabilitas (sig) sebesar 0,487 yang mana nilai tersebut diatas 0,05 .

Biaya operasional dan pendapatan opoerasional (BOPO) Bank Go Public di Indonesia mempunyai pengaruh negatif terhadap profitabilitas bank dengan koefisien regresi sebesar - 0,094. Hal ini dapat diartikan bahwa setiap peningkatan BOPO maka profitabilitas pada Bank Go Public di Indonesia mengalami penurunan atau sebaliknya setiap penurunan BOPO akan meningkatkan profitabilitas. Hipotesis diterima, karena dibuktikan dengan nilai probabilitas (sig) sebesar 0,000 yang mana nilai tersebut dibawah 0,05 .

Capital adequacy ratio (CAR) Bank Go Public di Indonesia mempunyai dampak negatif terhadap profitabilitas bank dengan koefisien regresinya sebesar 0,002. Ini dapat dijelaskan setiap adanya peningkatan Capital adequacy ratio (CAR) atau semakin tinggi CAR maka profitabilitas pada Bank Go Public di Indonesia akan mengalami penurunan. Hipotesis ditolak pada taraf signifikan $5 \%$, ini ditunjukkan melalui nilai probabilitas (sig) sebesar 0,556 di mana nilai probabilitas tersebut diatas 0,05 .

Non performin loan (NPL) Bank Go Public di Indonesia mempunyai pengaruh negatif terhadap profitabilitas bank dengan koefisien regresi sebesar - 0,083. 
Hal ini dapat diartikan bahwa setiap peningkatan NPL maka profitabilitas pada Bank Go Public di Indonesia mengalami penurunan atau sebaliknya setiap penurunan NPL akan meningkatkan profitabilitas. Hipotesis diterima, karena dibuktikan dengan nilai probabilitas (sig) sebesar 0,000 yang mana nilai tersebut dibawah 0,05.

\section{Analisis Regresi Linier Tahap 3}

Persamaan ketiga sebagai berikut

ROA $=-1,353+0,499$ NIM

Nilai konstanta pada penelitian ini diperoleh nilai - 1,353 yang dapat diartikan bahwa tanpa adanya perubahan dari variabel bebas atau variabel NIM maka profitabilitas (return on asset) pada Bank Go Public mengalami penurunan.

Net interest margin (NIM) Bank Go Public di Indonesia mempunyai pengaruh positif terhadap profitabilitas bank dengan koefisien regresi sebesar 0,499. Hal ini dapat diartikan bahwa setiap peningkatan NIM maka profitabilitas pada Bank Go Public di Indonesia mengalami peningkatan atau sebaliknya setiap penurunan NIM juga akan menurunkan profitabilitas. Hipotesis diterima pada taraf $5 \%$, karena dibuktikan dengan nilai probabilitas (sig) sebesar 0,000 yang mana nilai tersebut dibawah 0,05 .

\section{Koefisien Determinasi}

Berdasarkan hasil perhitungan diperoleh nilai koefisien determinasi (Adjusted $R$ Square) sebesar sebesar 0,172. Besar variasi variabel pendapatan bunga (net interest margin) pada Bank Go Public di Indonesia yang dapat diterangkan oleh variasi variabel LDR, BOPO, CAR dan NPL adalah sebesar 17,2 \%, sedangkan sisanya sebesar $82,8 \%$ dipengaruhi oleh variabel lain di luar model penelitian. Besar variasi variabel profitabilitas (return on asset) pada Bank Go Public di Indonesia yang dapat diterangkan oleh variasi variabel net interest margin (NIM) adalah sebesar 24,5 $\%$, sedangkan sisanya sebesar 75,5\% dipengaruhi oleh variabel lain di luar model penelitian

\section{Sobel Test}

\section{Peran Net Interest Margin dalam Mediasi Pengaruh Loan to Deposit Ratio terhadap Return on Investment}

Berdasarkan hasil perhitungan diperoleh nilai t sobel test sebesar 0,500 dan nilai $\mathrm{t}$ tabel sebesar 1,96. Perbandingan tersebut menunjukkan sobel test $>\mathrm{t}$ tabel $(0,500<$ 
1,96) sehingga dapat dijelaskan bahwa tidak ada peran net interest margin dalam memediasi pengaruh loan to deposit ratio terhadap return on investment. Hasil tersebut menunjukkan bahwa net interest margin tidak terbukti signifikan dalam memediasi pengaruh loan to deposit ratio terhadap return on asset pada Bank Go Public di Indonesia.

\section{Peran Net Interest Margin dalam Mediasi Pengaruh Biaya Operasional pada Pendapatan Operasional terhadap Return on Investment}

Berdasarkan hasil perhitungan diperoleh nilai sobel test sebesar - 7,046 dan nilai t tabel sebesar - 1,96. Perbandingan tersebut menunjukkan - sobel test $<-\mathrm{t}$ tabel $(-7,046<-1,96)$ sehingga dapat dijelaskan bahwa ada peran net interest margin dalam memediasi pengaruh biaya operasional pada pendapatan operasional terhadap return on investment. Hasil tersebut menunjukkan bahwa net interest margin terbukti signifikan dalam memediasi pengaruh biaya operasional pada pendapatan operasional terhadap return on asset pada Bank Go Public di Indonesia.

\section{Peran net Interest Margin dalam Mediasi Pengaruh Capital Adequacy Ratio terhadap Return on Investment}

Berdasarkan hasil perhitungan diperoleh nilai sobel test sebesar 0,499 dan nilai t tabel sebesar 1,96. Perbandingan tersebut menunjukkan sobel test $<\mathrm{t}$ tabel $(0,499<$ 1,96) sehingga dapat dijelaskan bahwa tidak ada peran net interest margin dalam memediasi pengaruh capital adequacy ratio terhadap return on investment. Hasil tersebut menunjukkan bahwa net interest margin tidak terbukti signifikan dalam memediasi pengaruh capital adequacy ratio terhadap return on asset pada Bank Go Public di Indonesia.

\section{Peran Net Interest Margin dalam Mediasi Pengaruh Non Performing Loan terhadap Return on Investment}

Berdasarkan hasil perhitungan diperoleh nilai sobel test sebesar - 4,371 dan nilai $\mathrm{t}$ tabel sebesar - 1,96. Perbandingan tersebut menunjukkan - sobel test $<-\mathrm{t}$ tabel $(-$ $4,371<-1,96)$ sehingga dapat dijelaskan bahwa ada peran net interest margin dalam memediasi pengaruh non performing loan terhadap return on investment. Hasil tersebut menunjukkan bahwa net interest margin terbukti signifikan dalam memediasi non performing loan pada pendapatan operasional terhadap return on asset pada Bank Go Public di Indonesia. 


\section{KESIMPULAN}

1. Berani mengambil tindakan dalam penambahan kredit kepada debitur - debitur yang dirasa atau berdasarkan analisis pembayarannya lancar dan melakukan ekspansi - ekspansi usaha jasa keuangan.

2. Memodifikasi atau mengembangkan produk jasa keuangan dengan cara pendampingan - pendampingan pada usaha - usaha yang dipandang produktif dan mempunyai tingkat pengembangan yang tinggi.

3. Tingkat CAR yang rata - rata masih tinggi menunjukkan bank masih banyak dana yang menganggur. Dana - dana tersebut dapat disalurkan kepada bisnis lain yang dirasakan berpontensi berkembang.

\section{DAFTAR PUSTAKA}

Ali, Muhammad dan Laksono, Roosaleh., 2017., Pengaruh Net Interest Margin (NIM), Biaya Operasional Terhadap Pendapatan Operasional BOPO), Loan to Deposit Ratio (LDR) dan Non Performing Loan (NPL) terhadap (ROA)., Jurnal Riset Akuntansi Dan Keuangan, Vol 5 Nomor 2, Bandung.

Alifah, Yonira Bagiani., 2014., Pengaruh CAR, NPL, BOPO, dan LDR terhadap Profitabilitas Bank (ROA) pada Perusahaan Perbankan tang Terdaftar di Bursa Efek Indonesia Periode 2009-2012., Skripsi., Program Studi Manajemen, FE., Universitas Negeri Yogyakarta.

Ariyanti, Indah., Dhiana, Patricia dan Pranaditya, Ari., 2017., Pengaruh CAR, NPF, NIM, BOPO, dan DPK terhadap Profitabilitas dengan FDR Sebagai Variabel Intervening (Studi Kasus Perbankan Umum Syariah Tahun 2011-2014)., Jurnal Akuntansi., Universitas Pandanaran.

Aprillya, Agnes., Effendi, Rizal, Nyimas Artina., 2017., Analisis Pengaruh Non Performing Loan (NPL), Loan to Deposit Ratio (LDR) dan Capital Adequacy Ratio (CAR) Terhadap Return On Asset (ROA) pada Bank BUMN yang Terdaftar di BEI Periode Tahun 2012 - 2016., Jurusan Manajemen., STIE Multi Data Palembang

Alshatti, Ali Sulieman., 2015., The Effect of the Liquidity Management on Profitability in the Jordanian Commercial Banks., International Journal of Business and Management; Vol. 10, No. 1; 2015

Almilia, Luciana Spica dan Winny Herdiningtyas, 2005. Analisis Rasio CAMEL terhadap Prediksi Kondisi Bermasalah Pada Lembaga Perbankan Periode 2000-2002. Jurnal Akuntansi dan Keuangan, Vol.7, No.2.

Astohar., 2013., Statistika Bisnis Kasus dan Solusi., Penerbit Duta Nusindo., Semarang.

Astohar., 2016., Pengaruh Capital Adequacy Ratio (Car) Dan Financing To Deposit Ratio Terhadap Profitabilitas Perbankan Bank Go Public Di Indonesia Dengan Inflasi Sebagai Variabel Pemoderasi., Among Makarti Vol.9 No.18, Desember 2016 
Astohar, 2018., Analisis Faktor - Faktor Yang Berpengaruh terhadap Profitabilitas Perbankan yang Go Public di Bursa Efek Indonesia pada tahun 2012 - 2016., Jurnak Dinamika Ekonomi \& Bisnis (JDEB)., Vol 15 No 1., Maret 2019

Astohar dan Praptitorini, Mirna Dyah., 2019., Model Struktural Faktor - Faktor yang Berpengaruh terhadap Profitabilitas dengan Net Interest Margin sebagai Variabel Intervening (Studi pada Bank Go Public di Indonesia Pada Tahun 2014 2018)., Balance

Profitabilitas,. E-Jurnal Manajemen, Vol. 8, No. 6,

Vocation Accouting Journal., Vol 3 No 2.

Fahmi, Irfam 2015, Manajemen Perbankan Konvensional \& Syariah, Penerbit Mitra Wacana Media, Jakarta.

Fajari, S dan Sunarto., (2017). Pengaruh CAR, LDR, NPL, BOPO terhadap Profitabilitas Bank (Studi Kasus Perusahaan Perbankan yang tercatat di Bursa Efek Indonesia Periode Tahun 2011 Sampai 2015 ). Prosiding Seminar Nasional Multi Disiplin Ilmu \& Call For Papers Unisbank Ke-3

Fauziah, Ravika, 2011., "Analisis Pengaruh Inflasi Terhadap Tingkat Profitabilitas Bank Muamalat Indonesia dan Bank Central Asia (BCA) Tahun 2007-2011", Universitas Negeri Surabaya, Surabaya, 2011

Ghozali, Imam, 2013, Manajemen Risiko Perbankan Pendekatan VaR, Badan Penerbit Universitas Diponegoro, Semarang.

Hery., 2015., Analisis Laporan Keuangan Pendekatan Rasio Keuangan., Yogyakarta : Center for Academic Publishing Services

Kasmir 2012, Manajemen Perbankan, Edisi Revisi, Rajawali Pers, Jakarta.

Kuncoro, Mudrajad dan Suhardjono. 2002. Manajemen Perbankan Teori dan Aplikasi. Yogyakarta; BPFE UGM.

Latifah, Nurul Maulidya, Rodhiyah, Saryadi. 2012, Pengaruh Capital Adequacy Ratio (CAR), Non Performing Loan (NPL) dan Loan to Deposit Ratio (LDR) terhadap (ROA) (Studi kasus pada Bank Umum Swasta Nasional Devisa Go Public di Bursa Efek Indonesia Periode 2009-2010)., Jurnal Ilmu Administrasi Bisnis., Semarang.

Martindas, Anggria Maya., Pangemanan, Sifrid S. dan David P.E. Saerang., 2013., Pengaruh Capital Adequacy Ratio (CAR), BOPO dan Non Performing Loan (NPL) terhadap Kinerja Keuangan Perbankan di Indonesia., Jurnal Unsrat.

Milion, Lie Jimmy., Utary, Anis Rachma., Irwansyah., 2017., Pengaruh Non Performing Loan dan Capital Adequacy Ratio serta Biaya Operasional terhadap Net Interest Margin dan Return On Asset., prosiding Seminar Nasional Manajemen dan Ekonomi Bisnis., Volume 1., Mei 2017.

Moslem, Orchidia Seta dan M. Chabachib, 2016., Analisis Faktor-Faktor Yang Berpengaruh Terhadap Profitabilitas Perbankan (Studi Perbandingan Bank Devisa dan Bank Non Devisa Di Indonesia Periode 2010-2014), Jurnal Bisnis dan Manajemen., Vol.4 No.4

Nisa, Chaerani., 2016., Aplikasi Teori Perilaku Manajemen pada Bank Milik Pemerintah di Indoensia., Jurnal Manajemen dan Pemsaran Jasa., Vole 9 No 2

Pandia, Frianto., 2012., Manajemen Dana dan Kesehatan Bank. Rineka Cipta., Jakarta Pertiwi, Loraine dan Susanto, Liana, 2019., Faktor Yang Mempengaruhi Profitabilitas Pada Perbankan yang terdaftar di Bursa Efek Indonesia., Jurnal Multiparadigma Akuntansi, Volume I No. 2 
Podpiera, J., \& Weill, L. (2008). Bad Luck or Bad Management? Emerging Banking Market Experience. Journal of Financial Stability, 4(2), 135t148.

Rahmani, Nur Ahmadi Bi., 2017., Analisis Pengaruh Capital Adequacy Ratio (CAR) dan Financing to Deposit Ratio (FDR) terhadap (ROA) dan Return On Equity (ROE) Pada Perusahaan Bank Bank Go Public di Indonesia., Jurnal Human Falah., Vol 4 Nomor 4. Yogyakarta.

Simorangkir, O.P. (2004). Pengantar Lembaga Keuangan Bank dan non Bank. Jakarta: Ghalia Indonesia.

Sitepu, Jurnal., Dzulkirom, Moch., Azizah, Devi Farah., 2016., Pengaruh Capital Adequacy Ratio, Biaya Operasional Per Pendapatan Operasional, Non Performing Loan, Net Interest Margin Dan Loan To Deposit Ratio Terhadap Return On Asset (Studi pada Perusahaan Sektor Perbankan yang terdaftar di Bursa Efek Indonesia Periode Tahun 2012-2015)., Jurnal Administrasi Bisnis (JAB)|Vol. 40 No. 2 November 2016

Sudarmawanti, Erna dan Pramono, Joko, 2017., Pengaruh CAR, NPL, BOPO, NIM dan LDR terhadap ROA (Studi kasus pada Bank Go Public di Salatiga yang terdaftar di Otoritas Jasa Keuangan Tahun 2011-2015)., AmongMakarti., Vol 10 No 19.

Sudarmanta, I Ketut 2016, Determinasi Profitabilitas Sektor Perbankan Di Bursa Efek Indonesia, Pascasarjana Universitas Warmadewa, Denpasar, Diakses 22 Agustus 2017, dari www.ejournal.warmadewa.ac.id

Taswan, 2010. Manajemen Perbankan Konsep Teknis \& Aplikasi. Penerbit UPP STIM YKPN Yogyakarta.

Wibisono, Muhammad Yusuf dan Wahyuni, 2017., Pengaruh CAR, NPF, BOPO, FDR, terhadap ROA yang Dimediasi oleh NOM., Jurnal Bisnis \& Manajemen Vol. 17, No. 1

Yuniari, Ni Putu Dan Badjra, Ida Bagus ., 2019., Pengaruh Likuiditas, Efisiensi, Dan Ukuran Bank Terhadap 